\title{
INDUSTRIAL RELATIONS IN FOREIGN AND LOCAL FIRMS IN ASIA.
}

Bhal J. Bhatt, Professor of Management and International Business, University of Toledo; and Edwin L. Miller, Professor of Industrial Relations, University of Michigan. Abstract taken from Management International Review 24, No. 3 (1984): 62-75.

The authors report their findings of an exploratory, comparative study of industrial relations in eight Asian firms. The study sought: (1) to assess the differences in the practice of industrial relations between MNCs and local firms; (2) to explain any differences that might be observed; (3) to verify if a monolithic MNC model of industrial relations exists; and (4) to understand the nature of change in national systems that can be attributed to MNCs.

Bhatt and Miller selected a local company (LC) and a foreign subsidiary (FS) of an MNC in India, Thailand, Singapore, and the Philippines. The two companies in each country were in the same manufacturing sector and had comparable product lines. Size of work force, scale of operations, technology, and age of firm were not controlled. The following industrial relations practices were compared for each pair of companies: the use of collective bargaining processes, written agreements, union membership, effectiveness of grievance procedures, and number of strikes and man-days lost due to strikes in 1976.

A random sample of male, non-supervisory personnel was selected and represented approximately 20 percent of each participating firm's work force. Trained interviewers gathered data through the use of guided interviews conducted in the local language. The random sample contained 1,223 employees, with 553 drawn from FS firms and 670 drawn from LC companies. Background information concerning the firm was gathered through interviews with managers, union leaders, and government officials.

With the exception of Thailand, the FSs had a much higher percentage of the labor force unionized. Both firms in Thailand and Singapore had collectively negotiated agreements while neither firm in either the Philippines or India had such an agreement. In every case the FSs had detailed, written employment contracts or handbooks. Only the Singapore LC had such a document-and it was vague. All firms except the LC in India had formal grievance procedures. The authors noted that the FS unions had an automatic check-off provision for the collection of union dues. In contrast, the LC firms had no similar provision. The FS firms made regular contributions to the unions for recreational and cultural activities, in addition to having recreational rooms and a bulletin board for employees.

All FS firms processed a much larger number of grievances and had substantially fewer days lost to strikes than LC firms. In two of the FS firms, no strikes occurred during the year studied. In Thailand and Singapore, strikes did occur in FS firms but they were of shorter duration than the strikes of the LC companies. It was concluded that the grievance processes in FSs apparently were successful since potential strike situations were avoided.

In the area of compensation, the FS firms offered substantially higher wages than the corresponding LC firm in every case. In India and Thailand, the wages paid by the FS firms were approximately twice the wages of the LC firms. Six of the eight firms exceeded the fringe benefit package mandated by law. The research was inconclusive as to whether FS or LC firms offered more perceived job security and advancement potential. 
The worker profile indicated that FS workers were substantially younger than their counterparts in LC firms. In addition, the FS firms hired more educated workers and a higher ratio of skilled-to-unskilled laborers. A much higher percentage of FS employees had received formal job training. Overall, Bhatt and Miller concluded from their research that an MNC monolithic model of industrial relations does exist. Evidence presented revealed very little MNC adaptation to local conditions in the areas of industrial relations studied. One of the severe limitations of this conclusion is that all FSs were part of the same MNC; therefore, one would expect somewhat standard industrial relations practices.

The authors were unable to draw definitive conclusions about the institutional impact of MNCs on industrial relations practices in host countries. However, given the low educational levels and skills in the labor market, Bhatt and Miller concluded that $L C s$ would have a difficult time competing for the young, educated and skilled workers sought by MNC subsidiaries. 